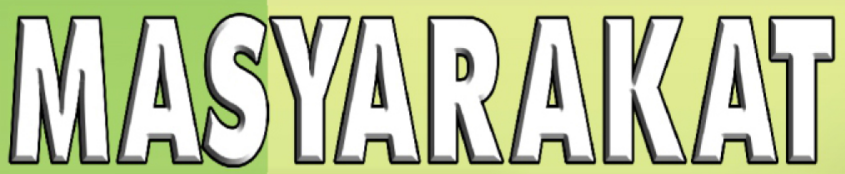

Terakreditasi No. 21/E/KPT/2018
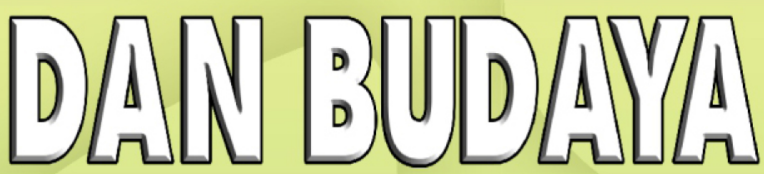

Volume 22 No. 12020

Karakter Keberagamaan di Jawa Pasca Geertz

Gutiono Bayu AJ]

Dayak Kaharingan di Tengah Perubahan Sosial Ekologi dan Praktik Perpindahan Agama dl Perdesaan Kalimantan Tengah

Nindyo Budi Kumoro

MarjinalisasI Hukum Adat pada Masyarakat Adat

The Suartina

Nasionalisme Masyarakat Natuna

Budlana Sotlawan

Frontierisation dan Defrontierisation Sebagal Kerangka untuk Studl Marjinalitas: Kasus Dataran Lindu di Sulawesi Tengah

Greg Acclalo/f dan Muhammad Nasrum

Marjinalisasi Perempuan Kuli Panggul di Pasar Pabean Surabaya

Mitranth Dwi Yuntart

Mencipta Ruang, Menggapal Langit: Pendidikan Publik Kritis dan Ruang Alternatif Minoritas di Yogyakarta dan Bandung Melke Lusye Karrolus dan Firchan Arta Wilaya

Adaptasi Sosial Gay Muslim Indonesia Terhadap Agama dan Keluarga Wisnu Adthariono 


\section{Daftar Isi \\ Jurnal Masyarakat dan Budaya \\ Volume 22 No. 1 Tahun 2020}

Pengantar Redaksi

Halaman

Topik:

iii

Ø5 Karakter Keberagamaan di Jawa Pasca Geertz

Gutomo Bayu Aji

\5 Dayak Kaharingan di Tengah Perubahan Sosial Ekologi dan Praktik Perpindahan Agama di Perdesaan Kalimantan Tengah

Nindyo Budi Kumoro

\5 Marjinalisasi Hukum Adat pada Masyarakat Adat

Tine Suartina

\5 Nasionalisme Masyarakat Natuna

Budiana Setiawan

\5 Frontierisation dan Defrontierisation Sebagai Kerangka untuk Studi Marjinalitas: Kasus Dataran Lindu di Sulawesi Tengah

Greg Acciaioli dan Muhammad Nasrun

§5 Marjinalisasi Perempuan Kuli Panggul di Pasar Pabean Surabaya

Miranti Dwi Yuniarti

\5 Mencipta Ruang, Menggapai Langit: Pendidikan Publik Kritis dan Ruang Alternatif Minoritas di Yogyakarta dan Bandung

Meike Lusye Karolus dan Firdhan Aria Wijaya

\5 Adaptasi Sosial Gay Muslim Indonesia Terhadap Agama dan Keluarga

Wisnu Adihartono

\section{Tinjauan Buku:}

\5 Membicarakan Masyarakat Pinggiran di Indonesia

Riwanto Tirtosudarmo 


\title{
MARJINALISASI PEREMPUAN KULI PANGGUL DI PASAR PABEAN SURABAYA
}

\section{MARGINALIZATION OF FEMALE PORTER IN PABEAN MARKET, SURABA YA}

\author{
Miranti Dwi Yuniarti \\ Fakultas Ilmu Sosial dan Ilmu Politik, Universitas Airlangga \\ miranti.dwis4@gmail.com.
}

\begin{abstract}
Marginalization often occurs in Indonesia, and it makes people gradually consider marginalization as a natural phenomenon. Female porters are one of the marginalized groups in Indonesia. They have been marginalized by others, but they do not realize it. This paper analyzes and describes the dilemmas and kind of marginalization faced by female porters in Pabean Surabaya market. The methods used in this study were qualitative, including direct observation and in-depth interviews. The results suggest that female porters marginalized by getting differential treatment by other people, they can not negotiate their wages with customers which makes the income they earn incommensurate with their hard work, which is also exacerbated by the wage differential between female porters and male porters. They also face some dilemmas related to their work such as: (1) having double burden as housewives and workers, (2)limited skills so they can not choose a better job for them, (3)insufficient income for daily needs, (4)social pressure from fellow workers and other people.
\end{abstract}

Keywords: dilemma, marginalization, female porters, Surabaya.

\begin{abstract}
Abstrak
Marjinalisasi sering terjadi di Indonesia dan hal ini membuat masyarakat secara tidak sadar menganggap marjinalisasi merupakan hal yang biasa, meskipun itu merupakan hal yang salah. Perempuan kuli panggul merupakan salah satu kelompok yang termarjinalkan di Indonesia. Mereka dimarjinalisasi oleh masyarakat, namun mereka sendiri tidak menyadarinya. Tulisan ini dibuat untuk menganalisis dan menjelaskan dilemadilema dan bentuk marjinalisasi yang dialami perempuan kuli panggul di pasar Pabean Surabaya. Metode yang digunakan adalah pendekatan kualitatif yang terdiri dari observasi langsung dan wawancara mendalam. Hasil penelitian menunjukkan bahwa perempuan kuli panggul mengalami marjinalisasi dengan cara diperlakukan berbeda oleh masyarakat. Mereka tidak dapat menawar upah, sehingga upah yang didapatkan tidak sesuai dengan kerja keras mereka. Upah mereka pun juga memiliki jumlah yang lebih sedikit daripada kuli panggul laki-laki. Dilema yang mereka hadapi sebagai kuli panggul adalah: (1)adanya beban ganda sebagai kuli panggul dan juga sebagai ibu rumah tangga, (2)kemampuan yang terbatas sehingga mereka tidak dapat memilih pekerjaan yang lebih baik, (3)pendapatan yang seringkali tidak dapat menutupi kebutuhan sehari-hari, (4)serta tekanan sosial dari sesama kuli panggul.
\end{abstract}

Kata kunci: dilema, marjinalisasi, perempuan kuli panggul, Surabaya.

\section{Pendahuluan}

Surabaya merupakan kota terbesar kedua di Indonesia dengan kebudayaan yang dinamis karena perpaduan berbagai etnis di dalamnya. Kebudayaan Surabaya bervariasi seiring banyaknya pendatang dari luar kota yang datang untuk bekerja. Kebutuhan ekonomi menyebabkan masyarakat melakukan urbanisasi ke kota yang lebih besar dengan harapan mendapatkan pekerjaan yang lebih baik. Namun, persaingan ketat tetap dihadapi oleh masyarakat sehingga tidak semua orang dapat bekerja di sektor formal. Sebagian lainnya bekerja di sektor informal. Kuli panggul merupakan salah satu pekerjaan di bidang sektor informal. Terdapat banyak jenis kuli panggul yang dibedakan berdasarkan tempat bekerja ataupun penyebutannya, namun umumnya identik dengan pasar tradisional. Salah satu pasar yang memiliki kuli panggul adalah pasar Pabean.

Pasar Pabean memiliki keunikan tersendiri. Berdasarkan sejarahnya, pasar ini dibangun sejak tahun 1849 pada era kolonialisme Belanda dan menjadi pusat perdagangan sejak abad ke-15. Hal ini menjadikan pasar Pabean adalah yang tertua di Surabaya. Pada masa sebelum kemerdekaan Indonesia, lokasi pasar Pabean ini dekat dengan pelabuhan Kalimas yang menjadi tempat kapal-kapal dari luar Jawa masuk ke 
Surabaya, serta pasar ini dekat dengan jalan Kembang Jepun yang dulunya dijadikan jalan perdagangan (Handelstraat) oleh penjajah Belanda.

Lokasi yang strategis tersebut menyebabkan pasar Pabean terus mengalami perkembangan hingga sedemikian rupa. Pasar ini menjadi unik tidak hanya karena sejarahnya, namun juga para pedagangnya yang hampir $97 \%$ adalah etnis Madura, sedangkan sisanya adalah pedagang dengan etnis Jawa dan etnis Tionghoa. Letak pasar yang berada di dekat Pecinan di jalan Kembang Jepun dan dekat dengan Kampung Arab di daerah pasar wisata religi Sunan Ampel memunculkan akulturasi budaya antara empat etnis, yaitu Jawa, Arab, Madura, dan Tionghoa. Hal ini menunjukkan bahwa adanya toleransi antar etnis menciptakan kerukunan yang terjaga hingga kini, terutama di pasar Pabean yang multi etnis.

Di pasar Pabean terdapat banyak perempuan yang bekerja sebagai kuli panggul. Kebutuhan masyarakat akan adanya pasar tradisional justru membuka lahan pekerjaan bagi perempuan kuli panggul sehingga mereka dapat memenuhi kebutuhannya tanpa harus memenuhi syarat-syarat tertentu. Pekerjaan ini pun cukup fleksibel, mereka tidak perlu terikat atau berkomitmen dengan pihak mana pun. Dalam penelitian ini, seluruh informan adalah ibu rumah tangga. Bekerja sebagai perempuan kuli panggul memberikan mereka kebebasan dalam mengatur waktu untuk pekerjaan di pasar dan di rumah. Namun, keuntungan-keuntungan tersebut tidak selamanya dapat menutupi kekurangan yang dirasakan oleh para perempuan kuli panggul ini.

Perempuan kuli panggul tergolong dalam kelompok marjinal, atau disebut pula kelompok terpinggirkan,yaitu kelompok minoritas yang tidak memiliki kekuatan untuk melawan sikap pembatasan yang dilakukan orang lain pada dirinya dan kelompoknya. Seringkali pembatasan ini bahkan menyebabkan mereka tidak mendapat hak-hak yang seharusnya diterima karena adanya rasa takut kepada kelompok lain yang dianggap lebih berkuasa. Hal ini dilatarbelakangi oleh berbagai hal seperti faktor pendidikan, status sosial, dan gender. Meskipunpara perempuan kuli panggul ini termarjinalisasi, tetapi mereka tidak memiliki pilihan selain melanjutkan pekerjaannya karena adanya desakan untuk memenuhi kebutuhan sehari-hari dirinya dan keluarganya.Kebutuhan tersebut tidak dapat terpenuhi hanya dari nafkah yang diterima darisuaminya.

Kuli panggul merupakan pekerjaan yang tidak mudah, terutama untuk perempuan karena membutuhkan banyak tenaga. Oleh sebab itu, pekerjaan ini umumnya dikerjakan oleh laki-laki. Beban yang dibawa pun tidak sedikit dan dapat mencapai puluhan kilogram. Namun pada kenyataannya, para perempuan kuli panggul ini mampu untuk memanggul beban tersebut demi keberlangsungan keluarganya. Bekerja sebagai perempuan kuli panggul juga memberikan dilema yang terkait dengan budaya patriarki.

Berangkat dari rasa kekaguman penulis ketika terhadap para perempuan kuli panggul yang mampu memanggul beban barang yang cukup berat dan berjuang keras untuk keluarganya, tulisan ini dibuat untuk mengetahui lebih dalam mengenai keseharian perempuan kuli panggul di pasar Pabean. Pekerjaan mereka yang nampaknya sederhana itu ternyata tidak sesederhana kelihatannya. Membawa barang dengan kepala dan bahu sebagai tumpuan rupanya sulit dipraktikkan tanpa adanya pengalaman. Pekerjaan yang meski dipandang sebelah mata oleh sebagian masyarakat, nyatanya sangat bermanfaat untuk membantu meringankan pekerjaan orang lain. Pada tulisan ini, penulis ingin berbagi cerita mengenai kehidupan perempuan kuli panggul terutama mengenai posisinya sebagai kelompok marjinal, yang kemudian dianalisis dengan teori gender milik Mosse.

\section{Tinjauan Pustaka}

\section{a. Gender}

Menurut Mosse (1996) jalan yang menjadikan kita maskulin atau feminin adalah gabungan blok-blok bangunan biologis dasar dan interpretasi biologis oleh budaya kita. Setiap masyarakat memiliki 'naskah' untuk belajar memainkan peran feminin atau maskulin seperti halnya bahasa yang dimiliki masyarakat. Gender merupakan peran yang digunakan untuk menyampaikan kepada orang lain bahwa kita adalah feminin atau maskulin. Lain halnya dengan jenis kelamin (sex), gender adalah definisi yang tidak permanen mengenai cara berperilaku. Gender dapat menjadi penentu pada akses terhadap pendidikan, kerja, dan sumber daya yang diperlukan untuk industri dan keterampilan. Gender dapat menjadi satusatunya faktor terpenting dalam membentuk kita 
akan menjadi apa nantinya. Mosse selanjutnya berpendapat bahwa ada dalam komunitas ada perbedaan pekerjaan yang dilakukan mereka dalam komunitasnya dan status maupun kekuasaan mereka di dalam masyarakat dapat berbeda pula.

Pembagian kerja dalam masyarakat dibedakan berdasarkan gender dan terdapat variasi pada pekerjaan laki-laki dan perempuan tergantung pada budaya suatu masyarakat. Sebagai contohnya, di Afrika, dalam masyarakat Mbuti, perempuan dan laki-laki dapat berburu bersama-sama dan keduanya juga memiliki peran aktif dalam pengasuhan anaknya. Pada masyarakat lainnya, perempuan dapat membajak sawah dan membangun rumah sedangkan lakilaki memasak dan membuat pakaian. Pembagian kerja secara seksual memiliki arti bahwa perempuan dianggap menjadi pencari nafkah tambahan dalam keluarga, sedangkan laki-laki adalah pencari nafkah utama tanpa memandang faktanya. Pada kenyataannya, di negara negara selatan, mayoritas perempuan miskin yang justru memungkinkan kelurganya dapat bertahan hidup. Semakin miskin suatu keluarga, maka semakin bergantung pula pada produktivitas perempuan.

Kemudian menurut Sadli (2010) dalam setiap lingkungan budaya terdapat pembagian peran gender (gender specific roles) yang dapat diamati, ditiru, atau diperkenalkan secara khusus pada anak laki-laki dan anak perempuan. Lalu dalam setiap budaya juga terdapat stereotip tertentu tentang apa yang 'pantas' untuk perempuan dan laki-laki. Stereotip pada setiap budaya dapat bervariasi dan dapat berubah dalam kurun waktu tertentu. Pada lingkungan budaya Indonesia masih ada kecenderungan kuat untuk menempatkan perempuan pada sektor domestik dengan pilihan yang relatif terbatas.

\section{b. Teori Feminisme Marxis dan Sosialis}

Dalam teori ini, feminis marxis dan sosialis percaya bahwa opresi terhadap perempuan bukanlah hasil dari tindakan satu individu, melainkan dari struktur politik, sosial, dan ekonomi tempat individu itu hidup. Feminis Marxis berpendapat bahwa eksistensi sosial menentukan kesadaran. Pepatah yang mengatakan bahwa "pekerjaan perempuan tidak pernah selesai" adalah lebih dari sekadar pepatah, namun sebuah kenyataan yang menggambarkan pekerjaan perempuan selama ini. Seorang perempuan membentuk konsepsi dirinya yang tidak akan dimilikinya jika perannya di dalam keluarga dan di tempat kerja tidak menahannya untuk tetap berada di bawah posisi laki-laki (subordinat) baik secara sosial maupun secara ekonomi, sehingga dalam upaya memahami mengapa perempuan teropresi.Ketika laki-laki tidak mengalaminya, diperlukan analisis hubungan antara status pekerjaan perempuan dan citra perempuan.

Terdapat konsep penting dalam feminisme marxis, yaitu alienasi atau keterasingan. Menurut Robert Heilbroner dalam Rosemarie (2008), alienasi adalah pengalaman yang secara mendalam mengakibatkan perasaan terfragmentasi atau terpecah belah, suatu benda dan atau manusia yang seharusnya berhubungan dengan cara yang signifikan justru dipandang sebagai terpisah. Berdasarkan pandangan feminis Marxis, terdapat empat cara eksistensi manusia kehilangan kesatuan dan keutuhannya antara lain.

(1) Manusia teralienasi dari produk kerja mereka. Pekerja tidak hanya tidak memiliki hak untuk mengutarakan pendapat mengenai komoditi yang ingin dihasilkan, namun mereka juga tidak mendapatkan buah hasil pekerjaan mereka, sehingga apa yang seharusnya membangun diri mereka sebagai pekerja akan menkonfrontasi mereka sebagai sesuatu yang asing.

(2) Pekerja teralienasi dari diri mereka sendiri. Ketika melakukan pekerjaan yang kurang menyenangkan sehingga harus dilalui dengan cepat, maka pekerjaan itu dapat mematikan. Jika sumber untuk memanusiakan pekerja menjadi sumber dehumanisasi (penghilangan kemanusiaan) maka pekerja melalui krisis psikologi yang sangat besar.

(3) Pekerja teralienasi dari pekerja lainnya karena struktur kapitalis yang mendorong pekerja untuk saling bersaing untuk memperoleh pekerjaan. Saat sumber komunitas pekerja menjadi sumber atas isolasinya, pekerja akan kehilangan identifikasi dengan segala sesuatu yang membangun dirinya.

(4) Pekerja teralienasi dari alam karena jenis pekerjaan yang dimiliki atau kondisi kerja mereka yang menyebabkan mereka menganggap alam sebagai hambatan terhadap kelangsungan hidup mereka.

Hal ini kemudian menghasilkan oposisi yang seharusnya keterhubungan itu ada menjadi tidak ada. Selanjutnya Foreman dalm Rosemarie (2008) berpendapat bahwa alienasi perempuan 
sangatlah mengganggu karena menyebabkan perempuan merasa bahwa dirinya bukanlah "diri" melainkan "liyan", sehingga rasa kepercayaan diri perempuan itu muncul dengan adanya penghargaan dari teman atau keluarganya terhadap kerja kerasnya.

\section{c. Penelitian-Penelitian Terdahulu}

Pada penelitian mengenai buruh gendong ini, Hapsari (2013) mendapatkan hasil mengenai beberapa faktor yang melatarbelakangi para perempuan bekerja sebagai buruh gendong di Pasar tradisional Semarang.Faktor ekonomi, seperti pemenuhan kebutuhan sehari-hari.Faktor sosial, yaitu lokasi pasar yang dekat dengan tempat tinggal sehingga dapat menghemat waktu dan tenaga serta memiliki status sebagai orangtua tunggal (single parents) sehingga harus mengambil alih peran pencari nafkah untuk keluarganya.

Faktor pendorong lainnya adalah pendidikan yang tidak tinggi, persyaratan buruh gendong yang mudah untuk dipenuhi, serta diperbolehkan oleh anggota keluarga. Mereka juga tetap dapat membagi waktunya untuk mengurus rumah tangga. Selain faktor pendorong, pada hasil penelitian Hapsari juga ditemukan faktor penghambat, yaitu beban ganda sebagai konsekuensi mereka yang berstatus sebagai ibu rumah tangga dan harus bekerja diluar rumah dan keadaan fisik yang kurang kuat sehingga tidak dapat digunakan bekerja sebagai buruh gendong terus menerus.

Penelitian tentang buruh gendong selanjutnya dilakukan oleh Eva Norma Sari dan Nur Hidayah (2017) di pasar Giwangan Yogyakarta. Penelitian Eva difokuskan pada faktor-faktor pendorong perempuan bekerja sebagai buruh gendong yang kemudian dianalisis dengan teknik analisis Miles dan Huberman. Berdasarkan penelitiannya, informan-informan Eva mendapatkan informasi mengenai pekerjaan buruh gendong melalui keluarga dan rekan. Mayoritas informan yang tidak memiliki pendidikan tinggi dan keterampilan khusus menyebabkan para perempuan tersebut bekerja menjadi buruh gendong.

Penelitian mengenai kuli panggul juga dilakukan oleh Hartonodan Salasin (2013) di desa Selotinatah, Kecamatan Ngariboyo, kabupaten Magetan. Penelitiannya difokuskan pada perempuan yang bekerja sebagai kuli panggul di Pasar sayur Magetan. Hasil penelitiannya adalah bahwa pekerjaan sebagai kuli panggul merupakan pekerjaan turun temurun dan sudah menjadi budaya perempuan di desa Selotinatah. Pekerjaan ini sudah menjadi budaya sejak tahun 1970-an. Meskipun mereka bisa bekerja sebagai TKW, tetapi mereka memilih bekerja sebagai kuli panggul karena ingin tetap bersama keluarganya dan menjalanlan peran ibu rumah tangga.

Penyebab lain mereka bekerja sebagai kuli panggul adalah kurangnya lahan pekerjaan di bidang pertanian, para perempuan pada umumnya bekerja ketika masa panen dan masa tanam.Ketika masa panen dan masa tanam berakhir, tidak banyak pekerjaan yang dapat dilakukan padahal mereka membutuhkan pendapatan untuk kebutuhan sehari-hari sehingga muncul ide untuk bekerja sebagai kuli panggul. Penyebab selanjutnya adalah kurangnya pendidikan dan kemampuan yang dibutuhkan untuk mendapatkan pekerjaan yang lebih baik dari kuli panggul sehingga mereka hanya dapat bekerja mengandalkan lebih banyak tenaga fisik.

Kemudian, ketertarikan bekerja mengikuti keluarga atau teman juga menjadi alasan yang melatarbelakangi para perempuan di desa Selotinatah bekerja sebagai kuli panggul. Hasil penelitian - penelitian yang telah disebutkan sebelumnya menunjukkan bahwa banyak faktor yang dapat melatarbelakangi perempuan untuk bekerja sebagai buruh gendong atau kuli panggul. Secara keseluruhan, terdapat tiga faktor utama penyebab perempuan bekerja sebagai kuli panggul, yaitu: (1) pendidikan yang kurang tinggi; (2) kondisi ekonomi yang kurang menguntungkan; (3) tidak memiliki kemampuan khusus untuk mendapatkan pekerjaan yang lebih baik. Namun selain faktor pendorong, ada pula faktor yang menghambat mereka untuk bekerja, yaitu fisik yang dimiliki tidak mampu untuk mengikuti kemauan dan semangat mereka dalam bekerja. Berdasarkan hasil-hasil penelitian tersebut, dapat dikatakan bahwa pada umumnya para kuli panggul tersebut memiliki latar belakang yang sama. Kemiskinan menjadi alasan utama bagi mereka untuk bekerja.

\section{Metode Penelitian}

Untuk memahami permasalahan yang dihadapi perempuan kuli panggul, penelitian ini menggunakan pendekatan etnografi, yaitu salah satu metode yang umum digunakan dalam antropologi. Etnografi bertujuan untuk 
mendeskripsikan suatu kebudayaan melalui sudut pandang masyarakat pemilik kebudayaan tersebut. Penelitian ini menggunakan metode etnografi, yaitu dengan mengamati, memahami, dan mempelajari kebudayaan yang dimiliki oleh para perempuan kuli panggul di Pasar Pabean Surabaya. Menurut Spradley (2007) etnografi memberikan deskripsi yang mengungkapkan berbagai model penjelasan yang diciptakan oleh manusia. Etnografi bertujuan untuk memahami kebudayaan masyarakat yang kompleks serta memahami perilaku manusia yang memiliki makna tertentu dalam kehidupannya.

Tipe penelitian ini adalah deskriptif kualitatif. Menurut Spradley (2007) deskripsi biasanya tampak sebagai bagian studi yang memfokuskan pada teori yang menguji hipotesis yang didasarkan pada pengamatan, wawancara, kuesioner, atau tes psikologi. Penelitian deskriptif bertujuan untuk merefleksikan sudut pandang penduduk asli mengenai suatu fenomena. Penelitian ini difokuskan pada kehidupan perempuan kuli panggul melalui sudut pandangnya sehingga mendapatkan data kualitatif yang akan disusun menjadi deskripsi tebal mengenai kebudayaan yang dipelajari.

Tipe penelitian ini digunakan agar penulis mendapatkan gambaran menyeluruh mengenai perempuan kuli panggul terutama mengenai pekerjaannya, posisinya dalam lingkungan kerja, pembagian waktu yang mereka lakukan dengan adanya tanggung jawab sebagai Ibu rumah tangga, dan hal-hal lain di dalam kehidupannya. Pengumpulan data dilakukan dengan wawancara mendalam.Total informan dalam penelitian ini adalah Sembilan informan yang terdiri dari enam perempuan kuli panggul dengan rentang usia 29-65 tahun sebagai informan kunci, dua pedagang, satu pengelola pasar (Kepala Pengelola Pasar Pabean), dan satu pembeli yang turut memberikan informasi mengenai perempuan kuli panggul.

Berdasarkan keterangan dari Kepala Pengelola Pasar Pabean, beberapa staf pasar, dan para perempuan kuli panggul, tidak ada jumlah pasti dari jumlah perempuan kuli panggul yang bekerja di Pasar Pabean. Pihak pengelola pasar pun tidak pernah mengambil data mengenai jumlah para kuli panggul tersebut disebabkan mereka merupakan jenis buruh lepas atau tidak memiliki komitmen dengan pihak mana pun. Sedangkan berdasarkan pengamatan penulis, jumlah perempuan kuli panggul yang bekerja pada waktu pagi hingga siang hari adalah sekitar 100 orang. Meskipun di malam hari juga terdapat kuli panggul, namun para perempuan kuli panggul tersebut lebih banyak bekerja di pagi hari karena mayoritas adalah ibu rumah tangga yang harus melakukan pekerjaan rumah tangganya di malam hari.

Selain wawancara, data juga dikumpulkan dengan observasi langsung di pasar Pabean Surabaya. Observasi dan wawancara dilakukan setiap tiga kali dalam seminggu selama empat bulan, yaitu sejak Februari 2018 hingga Mei 2018. Observasi juga dilakukan di beberapa tempat tinggal perempuan kuli panggul di Surabaya. Informan dipilih berdasarkan persyaratan informan menurut Spradley (2007).

(1) Enkulturasi penuh, informan yang mengetahui budayanya dan mampu menjelaskan dengan lancar dan baik karena keterlibatannya dalam budaya tersebut sudah dilakukan sejak lama hingga saat ini. Pada penelitian ini, yaitu kuli panggul yang sudah lama bekerja lebih dari tiga tahun;

(2) Keterlibatan langsung, dalam penelitian ini adalah perempuan kuli panggul yang masih aktif bekerja di Pasar Pabean;

(3) Suasana budaya yang tidak dikenal, semakin asing budaya yang diteliti oleh peneliti, maka semakin sensitif si peneliti dalam mengulik kebudayaan suatu kelompok. Hubungan yang produktif akan terjadi diantara informan yang terenkulturasi penuh dan peneliti yang tidak terenkulturasi penuh. Ketika perbedaan budaya semakin besar, maka semakin banyak permasalahan yang muncul dan informasi yang didapatkan semakin dalam;

(4) Cukup waktu, informan juga dipilih berdasarkan kesediaan mereka untuk diwawancarai dan diamati. Tidak sedikit perempuan kuli panggul yang enggan diwawancarai karena mereka tidak mau waktu kerjanya diganggu. Sedangkan wawancara juga tidak dapat dilakukan di rumah karena mereka tidak ingin waktu istirahatnya diganggu;

(5) Non analitik, yaitu informan tidak menggunakan sudut pandang dan ilmu-ilmu sosial untuk menganalisis tingkah laku mereka sendiri. Informan menjelaskan informasi menurut mereka apa adanya tanpa adanya intervensi sudut pandang orang lain atau ilmu sosial. 
Pemilihan informan dipusatkan pada wilayah pedagang bawang dan tekstil yang terletak di sisi timur Pasar Pabean yang bekerja mulai pagi hingga sore hari. Informan dipilih dari tiga titik di wilayah tersebut, yaitu bagian luar di sisi selatan, bagian dalam, dan bagian luar di sisi utara. Pemilihan informan ini dipengaruhi juga oleh keterbatasan penulis dalam hal waktu, biaya, dan tenaga.

Selain mengamati dan mendengarkan, hal selanjutnya yang perlu dilakukan dalam mempelajari kebudayaan adalah membuat kesimpulan. Ketika kita mengamati seseorang melakukan tindakan tertentu, maka kita menyimpulkan makna dan tujuan dari tindakan tersebut. Untuk membuat kesimpulan ketika melakukan kerja lapangan, terdapat tiga sumber, yaitu (1) dari hal yang dikatakan orang, (2) dari cara orang bertindak, dan (3) dari berbagai artefak yang digunakan orang. Pada awalnya hipotesis didapatkan melalui tiga sumber tersebut kemudian untuk memastikan bahwa masyarakat yang diteliti memiliki sistem budaya yang khusus perlu dilakukan pengujian secara berulangulang.

Pengetahuan budaya yang disampaikan secara eksplisit atau secara jelas mempermudah etnografer dalam membuat kesimpulan.Namun, pengetahuan budaya yang implisit memerlukan pengamatan yang lebih banyak agar kita dapat membuat kesimpulan. Meski begitu, bukan berarti bahwa pengetahuan yang eksplisit tadi kita tinggalkan dan lebih mengutamakan pengetahuan yang disampaikan secara implisit karena keduanya diperlukan dalam membuat kesimpulan budaya (Spradley, 2007: 95-103). Oleh karena itu, ketika kita mewawancarai informan, kita juga perlu untuk mengobservasi tindakan yang mereka lakukan, serta mewawancarai dan mengobservasi dari sudut pandang orang lain seperti pedagang dan pembeli mengenai perempuan kuli panggul agar data yang didapatkan semakin valid. Hasil pengumpulan data dalam bentuk rekaman wawancara, catatancatatan lapangan, data sekunder, dan dokumentasi kemudian di analisis menggunakan teori feminisme liberal yang selanjutnya ditulis dalam bentuk deskripsi dengan fokus perempuan kuli panggul sebagai kelompok marjinal.

\section{Perempuan Kuli Panggul di Pasar Pabean Surabaya}

Berdasarkan Kamus Besar Bahasa Indonesia (KBBI), panggul atau memanggul berarti membawa di atas bahu atau menjulang. Panggul merujuk pada cara para perempuan kuli panggul di pasar Pabean membawa barangnya di atas kepala dan bahu. Pada umumnya penyebutan kuli panggul di pasar-pasar tradisional merujuk pada bagaimana cara mereka membawa barangnya. Sebagai contohnya, di pasar tradisional Semarang, sebutan untuk kuli panggul di sana adalah buruh gendong, karena mereka membawa barang dengan cara menggendong atau beban ditumpukan pada punggung. Ada sebutan lain untuk kegiatan memanggul, yaitu nyungun (bahasa Jawa) atau nyu'un (bahasa Madura), sehingga sebutan lain untuk kuli panggul di pasar Pabean Surabaya adalah wong nyungun atau wong nyu'un. Meski mereka disebut kuli panggul, tetapi sesungguhnya mereka tidak terlalu suka dengan sebutan itu, karena menurut mereka kuli adalah orang yang disuruh-suruh, orang yang tidak boleh melawan pada atasannya, serta pekerjaan yang statusnya rendah.

Di Pasar Pabean, pedagang dan pembeli lebih sering memanggil mereka langsung dengan namanya, atau hanya memanggil 'bu' atau 'mbak'. Meski tidak ada aturan khusus untuk atribut yang dikenakan, namun perempuan kuli panggul ini, terutama yang berasal dari Madura, memiliki ciri khas sendiri dalam berpakaian. Perempuan kuli panggul yang berasal dari Madura memiliki ciri khas seperti menggunakan kerudung atau kain yang diikat di kepala, menggunakan atasan berupa kaos lengan pendek serta bawahan berupa kain batik atau sarung, dan menggunakan sandal jepit sebagai alas kaki, namun ada pula yang tidak menggunakan alas kaki sama sekali. Sedangkan perempuan kuli panggul dari Jawa biasanya hanya menggunakan atasan kaos lengan pendek dan bawahan berupa celana sepanjang lutut. Hal ini menjadi pembeda antara perempuan kuli panggul dan para pedagang yang biasanya hanya menggunakan kaos atau kemeja, namun jarang menggunakan bawahan sarung.

Di Pasar Pabean Surabaya, perempuan kuli panggul dapat ditemukan di setiap sudut pasar. Kisaran usia para kuli panggul tersebut adalah 15-60 tahun keatas. Mereka bekerja sejak pagi hari hingga sore hari, ada pula yang bekerja dari dini hari hingga pagi hari karena pasar Pabean ini aktif mulai dini hari. Kuli panggul adalah buruh pasar yang bertugas untuk membawa barang pelanggannya dari satu tempat ke tempat lainnya sesuai dengan permintaan 
pelanggan. Untuk sekali perjalanan membawa barang, mereka diberi upah sebanyak Rp. 2000 Rp.5000 untuk berapa pun berat barang yang dibawa dalam satu kali perjalanan tersebut. Tidak ada perbedaan antara upah untuk perempuan kuli panggul atau pun kuli panggul laki-laki. Namun kuli panggul laki-laki cenderung memiliki tenaga yang lebih banyak daripada perempuan kuli panggul sehingga mereka dapat bekerja lebih sering daripada perempuan kuli panggul. Dalam sehari, seorang perempuan kuli panggul dapat memanggul lima sampai dua puluh kali dalam sehari, namun kuli panggul laki-laki dapat bekerja lebih dari itu. Intensitas bekerja ini pun juga dipengaruhi oleh banyak pelanggan yang datang.

Berdasarkan keterangan perempuan kuli panggul, tidak ada jumlah yang pasti untuk penghasilan maupun intensitas kerja mereka dalam sehari.Perempuan kuli panggul tidak memasang tarif tertentu sehingga upah yang diberikan tergantung pada pelanggan. Di hari yang ramai, mereka mampu memperoleh Rp.50.000,- - Rp.100.000,- sedangkan di hari yang sepi pelanggan, mereka hanya mendapatkan Rp.20.000,- - Rp.30.000,- saja. Pada umumnya berat barang yang mereka bawa adalah $30-50 \mathrm{~kg}$ untuk sekali perjalanan.Nasib yang sama juga dialami oleh perempuan buruh gendong di Yogyakarta. Berdasarkan penelitian Estri (2016) di Pasar Beringharjo, Giwangan, dan Kranggan, perempuan buruh gendong mendapatkan upah sebanyak Rp.2000,- - Rp.5000,- untuk sekali menggendong dan Rp.25.000,- - Rp.40.000,dalam sehari.

Pekerjaan utama kuli panggul adalah memanggul barang persedian pasar, seperti bahan - bahan makanan berupa ikan, bawang merah, bawang putih, bawang bombay, kemiri, kluwek, tepung, kacang, buah-buahan, sayuran, dan lain-lain.. Pada umumnya mereka bekerja secara berkelompok. Dalam satu kelompok terdiri lima hingga enam orang yang terikat oleh hubungan keluarga, sehingga mereka bekerja dengan sanak saudaranya atau terkadang ada juga yang berdasarkan kesamaan wilayah asalnya.

Kelompok yang terbentuk atas ikatan keluarga atau kesamaan wilayahasal ini biasanya dilakukan oleh para perempuan kuli panggul yang berasal dari Madura.Ketika para perempuan kuli panggul tersebut tidak memanggul, mereka akan mengerjakan pekerjaan lainnya seperti menjaga kios, menampi bawang merah dan bawang putih untuk memisahkannya dengan kulit bawang yang sudah mengelupas, mengupas bawang (ngoncek), membersihkan cabai, membersihkan kluwek atau memunguti bawang dan cabai yang berserakan di sepanjang lorong pasar. Bawang dan cabai tersebut biasanya terjatuh dari karung - karung yang dibawa kuli panggul dan berceceran di sepanjang jalan dalam pasar, kegiatan ini disebut gélék (bahasa Jawa) yang artinya mencari, memungut, atau memulung.

Dari gélék mereka bisa mendapatkan bawang sebanyak setengah kilogram hingga enam kilogram. Terkadang mereka juga mengumpulkan sampah-sampah kering di dalam pasar kemudian diletakkan di dalam kantung plastik, apabila dirasa sudah cukup banyak, selanjutnya mereka memilahdan mengambil bawang atau cabai yang masih bagus. Setelah dikumpulkan, bawang atau cabai tersebut dijual ke pedagang yang khusus menerima persediaan bawang dari para kuli panggul saja. Harga yang ditawarkan di tempat tersebut lebih murah dibandingkan kios bawang lainnya, tergantung pada harga pasaran, sebagai contohnya jika harga bawang per kilogramnya adalah Rp.22.000,maka di kios tersebut akan dijual Rp.11.000,setengah dari harga pasaran. Jika tidak dijual ke pedagang, mereka juga dapat menjualnya sendiri. Ketika masih dini hari, banyak orang yang berjualan di sepanjang jalan Songoyudan, di tempat tersebut para kuli panggul tersebut dapat berjualan bawang hasil gélék. Untuk berjualan di jalan tersebut mereka harus membayar karcis seharga Rp. 2000,-.

Para pedagang tersebut diperbolehkan perjualan hingga jam tujuh pagi karena setelah itu jalan akan digunakan untuk parkir dan untuk jalur truk-truk yang membawa persediaan barang pasar. Di saat itu pula, kuli panggul mulai bekerja untuk memanggul barang-barang dari truk ke dalam pasar. Hal ini menunjukkan bahwa mereka mampu memanfaatkan waktu selama di Pasar Pabean dengan baik agar mendapatkan upah lebih banyak. Meski mereka menyebut pekerjaannya sebagai kuli panggul, namun kegiatannya tidak terbatas hanya memanggul barang sesuai permintaan pelanggan saja, kegiatanlain yang mampu mereka kerjakan.

Untuk pekerjaan seperti menampi dan mengupas bawang, jasa mereka dihargai Rp.10.000,untuk setiap lima kilogram bawang serta 
Rp.2500 untuk setiap lima kilogram kluwek. Kegiatan mengupas dan membersihkan cabai atau kluwek ini bersifat lebih fleksibel karena mereka dapat melakukannya dirumah apabila pekerjaan tersebut belum selesai dikerjakan di pasar. Contohnya, mereka mulai mengupas pada siang hari namun ketika waktunya pulang, pekerjaan tersebut belum selesai, maka mereka dapat membawa pulang barang kupasannya dan menyerahkannya pada keesokan harinya. Akan tetapi, sebelum barang dibawa pulang, perlu ditimbang terlebih dahulu beratnya, agar diketahui seberapa banyak barang yang dibawa pulang oleh kuli panggul tersebut. Oleh karena itu, jika mengupas kluwek, maka yang diserahkan kembali bukan hanya hasil kupasan namun juga kulitnya, agar ketika ditimbang kembali beratnya tetap sama. Hal ini dilakukan pedagang untuk menghindari adanya praktIk mencuri barang jualan oleh kuli panggul. Melalui kegiatan ini, pedagang dan kuli panggul dapat saling membangun kerjasama dan kepercayaan antara satu sama lainnya.

\section{Marjinalisasi pada Perempuan Kuli Panggul di Pasar Pabean Surabaya}

Perempuan kuli panggul merupakan kelompok marjinal, namun mereka tidak benarbenar merasa termarjinalkan. Dalam hal ini, maksudnya adalah mereka menerima status mereka dan perlakuan masyarakat terhadap mereka seakan-akan mereka tidak berhak untuk mendapatkan hak-hak yang seharusnya bisa mereka dapatkan seperti hak untuk menentukan jumlah upah yang sesuai dengan tenaga yang diberikan dan hak untuk dihormati atau tidak direndahkan. Para perempuan kuli panggul ini tidak merasa ada yang salah dengan kondisi mereka sebagai kuli panggul, sehingga ketika diwawancarai, masalah yang mereka ceritakan hanyalah masalah perekonomian rumah tangga mereka saja. Para perempuan kuli panggul tidak menyebutkan adanya masalah ketika mereka bekerja di pasar.

Beberapa faktor penyebab perempuan kuli panggul mengalami marjinalisasi adalah sebagai berikut.

\section{Pendidikan formal yang rendah}

Pendidikan merupakan hal yang penting untuk menentukan posisi kerja. Berdasarkan hasil wawancara dengan informan, para perempuan kuli panggul ini rata-rata adalah lulusan sekolah dasar (SD) atau Sekolah
Menengah Pertama (SMP), bahkan beberapa dari mereka tidak mampu untuk menempuh pendidikan formal dikarenakan tidak adanya biaya untuk menempuh pendidikan formal. Pendidikan yang pernah mereka tempuh umumnya adalah pendidikan agama di pondok pesantren atau tempat mengaji dan di sana mereka tidak belajar pengetahuan umum, sebagaimana informasi yang diberikan Rokizah (35 tahun) pada kutipan berikut ini.

"ndak sekolah, dek... nak adeg, sekolaah apa itu, sekolah Madura itu... hmm, disekolahin cuma disuruh salat, ngaji, auratnya suruh ditutupin, bukan disuruh cari kerjaan kayak sekarang hehehe kalau sekarang ya cari uang." (Rokizah, 21 Maret 2018)

Selain itu mereka juga tidak belajar keterampilan khusus yang dapat digunakan untuk bekerja.Kebutuhan ekonomi yang mendesak menyebabkan para perempuan kuli panggul itu sudah bekerja sejak mereka masih muda. Seperti yang diungkapkan Parmi (33 tahun), perempuan kuli panggul asal Surabaya, bahwa Dia telah bekerja di pasar Pabean sejak usia tujuh tahun, hanya sempat dua tahun menempuh pendidikan di sekolah dasar dan selanjutnya ia mengikuti orangtuanya bekerja di pasar. Parmi sempat berganti-ganti pekerjaan, tetapi karena tidak memiliki latar belakang pendidikan formal, maka pilihan lapangan pekerjaan pun terbatas. Mengikuti kakaknya di Jakarta, Parmi sempat bekerja sebagai kuli bangunan, pembantu rumah tangga, tukang sapu jalanan, pramuniaga, pemulung, dan lain sebagainya.

Kemudian,dia akhirnya kembali ke Surabaya karena lari dari salah satu majikan yang ingin menikahinya. Meski berganti-ganti pekerjaan, tetapi semua pekerjaan yang dimilikinya tidak membuatnya terlepas dari kemiskinan. Ketika kembali ke Surabaya pun, Parmi memilih menjadi kuli panggul karena penghasilan yang bisa didapatkan secara harian. Hal ini menunjukkan betapa terdesaknya Parmi untuk memenuhi kebutuhan sehari-harinya. Budaya patriarki sudah cukup memberikan pembatasan atas apa yang dikerjakan perempuan, ditambah dengan rendahnya pendidikan, menyebabkan perempuan kuli panggul berada dalam posisi yang semakin terhimpit.

\section{Stereotipe negatif dari orang lain}

Kuli selalu identik dengan pekerjaan kasar dengan upah yang sangat rendah. Dalam 
budaya patriarki,perempuan selalu dianggap sebagai makhluk tidak berdaya dan bergantung pada laki-laki terutama dalam masyarakat. Adanya pelabelan ini menyebabkan peran perempuan dalam masyarakat menjadi tidak kentara. Perempuan kuli panggul pun juga mendapatkan dampak negatif dengan adanya pelabelan tersebut.Para perempuan kuli panggul selalu dipandang sebelah mata oleh orang lain. Hal ini menimbulkan perasaan tidak percaya diri pada perempuan kuli panggul. Mereka tidak mampu untuk mengekspresikan dirinya dengan lebih baik. Berikut adalah pernyataan Parmi mengenai pendapat orang lain terhadap dirinya.

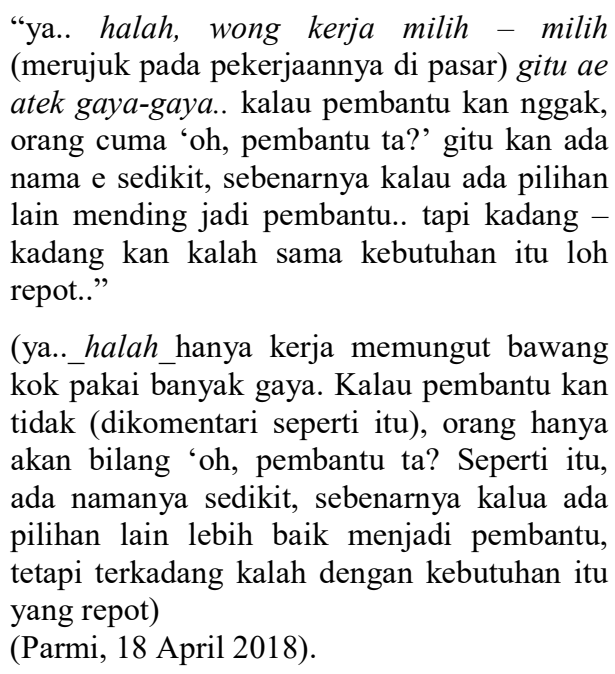

(ya.. halah hanya kerja memungut bawang kok pakai banyak gaya. Kalau pembantu kan tidak (dikomentari seperti itu), orang hanya akan bilang 'oh, pembantu ta? Seperti itu, ada namanya sedikit, sebenarnya kalua ada pilihan lain lebih baik menjadi pembantu, tetapi terkadang kalah dengan kebutuhan itu yang repot)

(Parmi, 18 April 2018).

Pernyataan Parmi tersebut menunjukkan bahwa baginya dan orang-orang di sekitarnya, kuli panggul merupakan pekerjaan yang lebih rendah dari pembantu rumah tangga, hanya karena pekerjaan kuli panggul yang terkesan lebih sederhana. "kerja milih-milih" dalam kalimat Parmi merujuk pada pekerjaannya mengumpulkan dan memilah-milah bawang yang ditemukannya di pasar. Parmi sesungguhnya ingin memilih menjadi pembantu rumah tangga, namun hal tersebut akan membuatnya kesulitan untuk membeli kebutuhan per hari karena upah pembantu rumah tangga adalah diberikan per bulan. Tidak seperti kuli panggul yang mendapatkan upahnya per hari. Masyarakat menganggap apa yang disebut 'pekerjaan' adalah sesuatu yang dilakukan di luar rumah, sesuatu yang terikat dengan atasan atau tempat tertentu, sesuatu yang menghasilkan banyak uang.Oleh sebab itu, hal ini berkaitan pula dengan status kerja domestik atau pekerjaan ibu rumah tangga tidak dianggap sebagai sebuah pekerjaan.
Meskipun pekerjaan yang dilakukan Parmi dan perempuan kuli panggul lainnya bukannya pekerjaan yang hina, namun pendapat orang lain menyebabkan mereka pun berpikir negatif mengenai apa yang mereka lakukan. Stereotip negatif menyebabkan mereka melupakan bahwa kuli panggul pun memiliki peran yang penting dalam keberlangsungan produktivitas pasar. Tanpa para kuli panggul, pedagang mau pun pembeli akan merasakan kesulitan dalam bisnis yang mereka lakukan di pasar.

\section{Perempuan kuli panggul tidak mengetahui} haknya.

Mereka selalu berpikir rendah tentang diri mereka sendiri, sehingga mereka cenderung menerima tidak peduli berapa banyak orang membayar untuk pekerjaan mereka.Seperti yang telah disbutkan sebelumnya, pendapatan mereka rendah sehingga tidak sepadan dengan kerja keras mereka. Namun,mereka tidak menaikkan biaya pembayaran mereka karena takut tidak akan mendapat banyak pelanggan. Pendapatannya bahkan berbeda antara kuli panggul laki-laki dan perempuan kuli panggul karena kuli panggul laki-laki dapat mengangkat lebih berat dari perempuan kuli panggul sehingga kuli panggul laki-laki memiliki intensitas bekerja yang lebih besar dibandingkan perempuan kuli panggul. Hal ini dibuktikan dengan pernyataan Rokizah.

"ya kalo orangnya pelit ya 3000, kadang 2000, 2000 itu lima puluh kilo..kalo yang kasihan itu baru ngasih $5000 \ldots$ ya kadang lima puluh sehari.. kalau sepi bisa tiga puluh, dua puluh, kalau ndak ada penglaris ya pulang.."

(Rokizah, 21 Maret 2018)

Saidah (50 tahun) pun turut mengungkapkan hal yang sama dengan Rokizah.

"ya tergantung orangnya dek... sekali ngangkat kadang - kadang ada yang sepuluh ribu... kadang lima ribu... nggak tentu... orang yang kasihan ya ngasih banyak."

(Saidah, 21 Maret 2018)

Pernyataan Rokizah tersebut menunjukkan bahwa dibandingkan dia bernegosiasi untuk menaikkan upah yang diterimanya sesuai dengan tenaga yang dikeluarkan.Da lebih memilih belas kasih pelanggannya untuk upah yang lebih besar. Terkungkung dalam pemikiran bahwa kuli panggul bukanlah pekerjaan yang berarti, para perempuan kuli panggul ini tidak berani untuk 
melangkah ke luar stereotip yang diberikan pada mereka untuk mendapatkan haknya. Di satu sisi mereka terbebas dari komitmenpekerjaan, namun mereka tidak terbebas dari stereotip masyarakat, sebagaimana hal tersebut diungkapkan oleh Parmi.

"mau kerja jadi pembantu rumah tangga ae kan ada namanya sedikit. ga terlalu direndahkan orang kan."

(Parmi, 18 April 2018)

Begitu pula dengan pendapat Sa'diyah mengenai kuli panggul.

"kuli artinya disuruh-suruh bos. diperintah bos ya berangkat. suruh nyungun ya mau... Namanya kuli makanya aku mau jadi bos, mau punya karyawan. Pengennya gitu... makanya kalau ndak nasib ya dipanggil kuli panggul"

(Sa'diyah, 21 Maret 2018)

Dua kutipan tersebut menunjukkan bahwa pendapat orang lain terhadap pekerjaan mereka tidak cukup baik. Kuli dianggap sebagai pekerjaan yang lebih rendah daripada pembantu rumah tangga dan hanyalah buruh yang dapat diperintah tanpa dapat mengekspresikan diri lebih baik. Di pasar Pabean tidak terdapat fasilitas yang dapat membantu meringankan beban para kuli panggul ini. Fasilitas yang ada hanya lebih diperuntukkan pedagang dan pembeli.Seperti yang dijelaskan sebelumnya, para perempuan kuli panggul ini bekerja sejak pagi hingga sore hari. Jika mereka merasa lelah, mereka hanya bisa beristirahat di sudut pasar, di pinggiran toko, di lantai pasar,bahkan beberapa di antaranya tidur di atas meja untuk display dagangan ketika toko tersebut tutup.

Meskipun Pasar Pabean merupakan pasar tertua di Surabaya dan merupakan cagar budaya, namun pengelola pasar Surabaya tidak memberikan fasilitas atau pun pembinaan kepada para kuli panggul. Para kuli panggul ini juga tidak dinaungi oleh sebuah lembaga swadaya masyarakat seperti para buruh gendong di Yogyakarta yang dinaungi oleh YASANTI (Yayasan Annisa Swasti), sebuah lembaga swadaya masyarakat yang bergerak dalam bidang pengembangan peranan wanita (Estri, 2016). Para kuli panggul ini juga tidak dikoordinir, sebagaimana kuli panggul di stasiun kereta api (porter) yang dikoordinir oleh seorang ketua. Meskipun para porter ini tidak dikelola secara langsung oleh PT. KAI, namun para porter tetap mendapatkan pembinaan dari PT. KAI (Aditya, 2019).

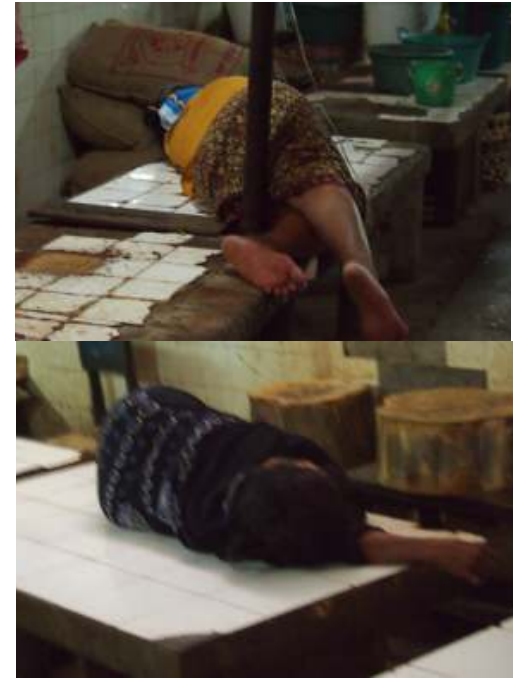

Gambar 1

Perempuan kuli panggul yang tidur di pasar Pabean Sumber: dokumen pribadi

Sebagaimana dalam pandangan feminis Maxis mengenai empat cara manusia kehilangan keutuhannya, yaitu ketika manusia teralienasi dari produk kerja mereka. Perempuan kuli panggul tidak memiliki hak untuk mengutarakan

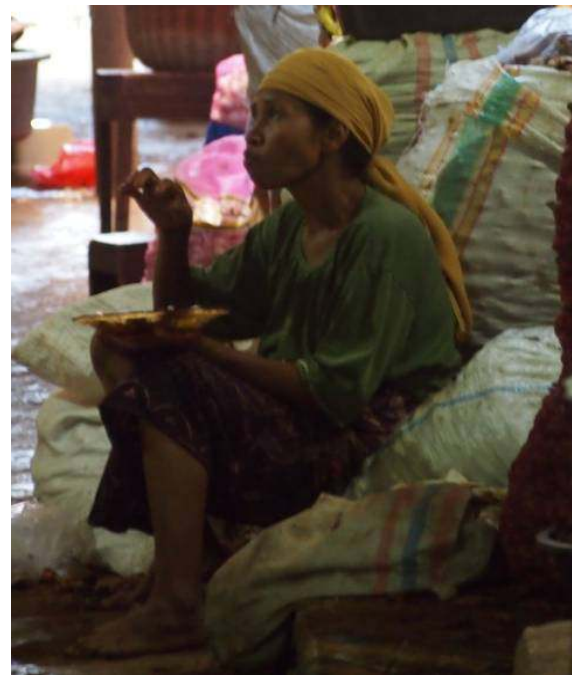

Gambar 2

Perempuan kuli panggul yang sedang makan di sudut pasar

pendapatnya mengenai komoditi yang dihasilkan, mereka tidak mendapatkan pendapatan yang sesuai dengan jerih payah mereka, namun mereka tidak dapat berbuat banyak tentang itu. 


\section{Dilema Perempuan Kuli Panggul di Pasar Pabean Surabaya}

Bekerja sebagai kuli panggul tidaklah semudah kelihatannya, apalagi jika kuli panggul tersebut adalah perempuan. Banyak hal yang menyebabkan dilema di kala mereka bekerja sebagai kuli panggul. Beberapa dilema yang dialami perempuan kuli panggul di pasar Pabean Surabaya adalah sebagai berikut.

\section{Beban Ganda}

Sebagai perempuan yang hidup dalam budaya patriarki, perempuan kuli panggul harus bekerja tidak hanya ketika di pasar, namun juga di rumah sebagai ibu rumah tangga. Mereka harus mengerjakan seluruh pekerjaan rumah tanggameskipun pekerjaan mereka di pasar Pabean sudah cukup berat untuk dilakukan. Jika mereka tidak mengerjakan pekerjaan rumah tangga, maka suami dan orang-orang di sekitarnya akan menganggap bahwa dia telah menelantarkan keluarganya. Perempuan diharuskan untuk menyiapkan rumah yang nyaman dan tenang untuk suami dan anak-anaknya (Saptari and Holzner, 2016). Dalam hal ini, bekerja sebagai kuli panggul memberikan kemudahan untuk mengatur jam kerja di pasar dan jam bekerja di rumah. Mereka dapat bekerja kapan pun sesuka mereka.

Hal ini pula yang menyebabkan para perempuan kuli panggul ini tetap memilih kuli panggul dari sekian pekerjaan yang dapat dilakukan. Seandainya mereka bekerja sebagai pembantu rumah tangga, maka mereka akan terikat dengan majikannya dan tidak dapat mengerjakan pekerjaan lainnya. Meski samasama bekerja, tetapi tidak ada pembagian kerja rumah tangga di antara suami dan istri. Pandangan pekerjaan rumah tangga merupakan pekerjaan perempuan masih sangat terasa dalam keluarga para perempuan kuli panggul ini. Bahkan beberapa di antaranya pun tidak saling terbuka mengenai pendapatan yang didapatkan.

Retni (29 tahun) misalnya, suaminya bekerja di Kalimantan sebagi kuli bangunan dan hanya pulang setahun sekali, sedangkan Retni berada di Surabaya bersama kakaknya, hidup di pinggiran sungai JMP (Jembatan Merah Plaza) sedangkan anak-anaknya hidup di desa bersama orangtuanya. Berdasarkan pengakuan Retni, suami tidak memberikan uang untuk kebutuhan sehari-hari pada Retni.Dia tidak berani menanyakan gaji suami karena takut akan memicu pertengkaran. Selama suami masih mau membayari biaya sekolah anaknya, Retni tidak mempermasalahkan hal tersebut, sehingga Retni pun mencukupi kebutuhan dirinya dan anaknya dengan caranya sendiri. Bahkan demi menghemat uang yang didapatkan, dia rela untuk tinggal di pinggiran toko. Begitu pula dengan Usnawati (36 tahun). Dia tidak berani menanyakan penghasilan suaminya selama suami mau untuk membantu terutama dalam masalah biaya sekolah anak.

Kedua cerita ini menunjukkan bahwa meskipun perempuan kuli panggul inijuga bekerja. Namun, mereka tidak merasa berhak menanyakan penghasilan suami, yang seharusnya dapat dibicarakan bersama agar penggunaan uang penghasilan dapat lebih efektif. Sementara mereka kesulitan untuk menutupi kekurangan yang dihadapi ketika memenuhi kebutuhan sehari-hari. Mereka lebih memilih diam demi kedamaian di dalam rumah tangganya dan lebih rela mencari uang sendiri untuk memenuhi kebutuhan anaknya. Belum lagi dengan tanggung jawab rumah tangga yang sepenuhnya dikerjakan oleh para perempuan kuli panggul ini. Puspita (2012) menyebutkan bahwa perempuan bekerja di rumah bertujuan untuk memenuhi kewajiban sosialnya sebagai ibu rumah tangga dan bekerja di luar rumah sebagai pemenuhan hidup anggota keluarganya, sehingga perempuan memperalat pekerjaan sebagai pemenuhan kebutuhan orang lain. Perempuan kehilangan hakikatnya sebagai manusia dan bekerja tidak lagi menjadi media pengembangan diri.

Dalam hal ini, bekerja tidak lagi menjadi hal yang diharapkan demi dirinya sendiri. Namun dilakukan untuk orang lain untuk keluarganya. Perempuan kuli panggul pun teralienasi dari pekerjaannya.Sebagaimana yang diungkapkan Foreman, perempuan tidak menjadi "ada", namun menjadi "liyan" ketika melakukan hal yang tidak dilakukan untuk dirinya saja, sehingga rasa kepercayaan diri perempuan sebenarnya datang dari dukungan orang di sekitarnya, terutama keluarganya. Ungkapan rasa terima kasih dan kasih sayang menjadi bentuk penghargaan paling besar untuk mereka.

\section{Tekanan Sosial dari Sesama Perempuan Kuli Panggul}

Seperti yang telah disebutkan dalam subbab sebelumnya bahwa perempuan kuli panggul bekerja dalam kelompok kecil yang pada umumnya dalam satu kelompok tersebut 
masih ada ikatan kekerabatan, terutama para perempuan kuli paggul yang berasal dari Madura. Meski begitu, permasalahan internal terkadang terjadi ketika mereka saling bersaing dalam memperoleh penghasilan. Sebagai contohnya, berdasarkan dari wawancara pada para informan tersebut, terkadang para perempuan kuli panggul ini saling iri satu sama lain ketika seseorang di antara mereka memiliki penghasilan yang lebih banyak. Perempuan kuli panggul yang merasa iri biasanya akan menuduh perempuan kuli panggul lainnya melakukan hal yang buruk, seperti mencuri, atau ada pula yang memaksa untuk membagikan hasil jerih payahnya tersebut karena merasa bahwa seharusnya semua orang dalam kelompok mendapatkan hasil yang sama. Dalam hal ini, perempuan kuli panggul teralienasi ketika perempuan kuli panggul saling bersaing untuk mendapatkan pekerjaan karena situasi ekonomi yang mendesak, melupakan ikatan kekerabatan dalam komunitas bekerja.

Meski pada kenyataannya, kemungkinan bahwa jumlah pendapatan yang bervariasi dalam suatu kelompok kuli panggul memiliki persentase yang besar karena mereka dapat melakukan pekerjaan lain di pasar. Pekerjaan yang tidak memerlukan kerjasama kelompok untuk melakukannya, sehingga dalam hal ini aktivitas perempuan kuli panggul di pasar pabean dapat digolongkan dalam dua jenis, yaitu (1) kerja kelompok yang berupa mengangkat barang persediaan pedagang dari truk pembawa barang ke toko pedagang dan selanjutnya (2) adalah kerja individual seperti membersihkan cabai, mengupas kluwek, menampi bawang, dan lain sebagainya. Banyak tidaknya penghasilan bergantung pada seberapa banyak pekerjaan yang mampu mereka lakukan di pasar. Bahkan, terkadang ada pula dari mereka yang memiliki pekerjaan lain di luar pasar. Jumlah penghasilan ditentukan oleh seberapa aktif para perempuan kuli panggul ini mencari pekerjaan di pasar.

Kembali pada permasalahan tekanan sosial dalam kelompok, hasil wawancara dan observasi menunjukkan bahwa lebih dari $90 \%$ perempuan kuli panggul berasal dari Madura yang kebanyakan datang ke pasar Pabean karena adanya kebutuhan ekonomi yang mendesak serta adanya ajakan dari kerabatnya untuk bekerja di sana. Berdasarkan keterangan para informan, sulit bagi orang baru untuk masuk dan ikut bekerja terutama yang tidak memiliki hubungan kerabat atau pun memiliki kenalan dari kelompok perempuan kuli panggul tersebut.
Perempuan kuli panggul yang baru bekerja di pasar Pabean diperlakukan sebagai orang asing dan bahkan terkadang dimintai uang oleh para perempuan kuli panggul yang sudah tua. Pendatang baru terutama yang masih muda juga rawan mendapat perlakuan tidak senonoh dari kuli panggul laki-laki, sehingga dapat dikatakan pula bahwa faktor penarik yang menyebabkan mereka bekerja di pasar Pabean adalah adanya rasa aman dan tenang ketika mengetahui adanya seseorang yang mereka kenal di pasar tersebut.

\section{Kemampuan Individual yang Terbatas}

Dilatarbelakangi oleh pandangan budaya patriarki yang menganggap bahwa perempuan akan menjadi ibu rumah tangga yang mengurusi pekerjaan rumah tangga dan keluarganya, pendidikan pun dianggap tidak terlalu penting. Namun kini, saat suami sebagai pencari nafkah tidak mampu untuk memberikan penghasilan yang cukup untuk memenuhi kebutuhan seharihari, istri pun terpaksa bekerja. Saat seperti ini lah baru disadari betapa pentingnya pendidikan untuk perempuan. Perempuan yang selalu berada dalam ranah domestik tiba-tiba diharapkan dapat mencari penghasilan tanpa adanya bekal keterampilan apapun. Namun, mereka tidak memiliki banyak pilihan dalam situasi ini, kecuali untuk mengorbankan dirinya bekerja demi kelangsungan hidup keluarga.

Hartini (2012) dalam jurnalnya mengenai pemberdayaan ekonomi perempuan, menuliskan alasan-alasan perekonomian perempuan perlu untuk dipertimbangkan, salah satu di antaranya adalah pemberdayaan ekonomi berkontribusi terhadap pengurangan kekerasan berbasis gender, meningkatkan kesempatan perencanaan keluarga dan memperlambat penyebaran HIV/AIDS. Pemberdayaan perempuan dapat mengatasi hubungan yang bersifat eksploitatif di lingkungan karena mereka tidak lagi tergantung secara ekonomi atas pasangannya. Alasan demikian yang membuat pemberdayaan perempuan adalah hal yang penting.

Salah satu cara untuk meningkatkan pendapatan para perempuan kuli panggul ini adalah dengan cara memberikan pembinaan atau kelas pelatihan untuk keterampilan tertentu. Parmi merupakan salah satu perempuan kuli panggul yang mengaku mengikuti pembinaan yang diberikan Dinas Sosial Surabaya, namun karena kegiatannya sangat banyak, dia tidak sempat mengerjakan pekerjaan rumah tangganya 
sehingga akhirnya memutuskan untuk berhenti mengikuti kegiatan Dinas Sosial. Ada baiknya jika kegiatan sosial maupun pelatihan tersebut disesuaikan dengan waktu bekerja sebagai ibu rumah tangga oleh para perempuan yang ingin mengikuti kegiatan Dinas Sosial agar kegiatan tersebut dapat lebih efektif untuk pengembangan keterampilan individu, terutama pada perempuan kuli panggul sehingga mereka dapat menggunakan keterampilan tersebut untuk mendapatkan pekerjaan yang lebih baik.

Pengelola Pasar Surabaya pun juga dapat membantu meningkatkan pendapatan para kuli panggul ini seperti dengan memberikan pembinaan untuk meningkatkan kualitas pelayanan mereka terhadap pelanggan, memberikan tempat istirahat, atau seragam seperti para porter di stasiun kereta api, namun disesuaikan dengan budaya atau lingkungan mereka. Hal ini diharapkan dapat mengubah cara pandang masyarakat mengenai kuli panggul terutama para perempuan kuli panggul yang selama ini terabaikan dan diharapkan pula dapat meningkatkan pendapatan para perempuan kuli panggul serta meningkatkan kualitas pelayanan yang ada di Pasar Pabean sehingga menarik semakin banyak pembeli dan wisatawan.

\section{Penutup}

Perempuan kuli panggul adalah salah satu kelompok pekerja yang mengalami marjinalisasi karena adanyapandangan bahwa kuli panggul adalah pekerjaan kasar yang umumnya dilakukan laki-laki dan adanya pelabelan dalam budaya patriarki bahwa perempuan memiliki sifat tidak berdaya menyebabkan mereka dihadapkan dengan adanya sikap meminggirkan dari masyarakat serta tanggung jawab sebagai ibu rumah tangga menjadikan para perempuan kuli panggul ini juga mengalami keterasingan atau alienasi dari dirinya sendiri maupun dari hasil kerja kerasnya dikarenakan mereka tidak lagi bekerja untuk dirinya, namun untuk orang lain. Pekerjaan yang dilakukan tidak menjadi media pengembangan diri, penghasilan yang didapatkan tidak untuk dirinya, bekerja pun sesungguhnya terasa tidak menyenangkan, namun semua itu dilakukan untuk keberlangsungan hidup keluarganya. Ketika suami tidak mampu untuk memenuhi kebutuhan sehari-hari hanya dengan pendapatannya, para perempuan kuli panggul ini rela untuk bekerja sebisa kemampuan mereka. Tidak adanya kererampilan tertentu ditambah dengan tidak ada latar pendidikan formal menjadikan pilihan kerja menjadi sangat terbatas. Namun para perempuan kuli panggul ini mampu untuk tetap bertahan dalam semua masalah yang dihadapinya merupakan suatu hal yang patut diapresiasi.

Berdasarkan hasil penelitian ini, dapat disimpulkan bahwa peran pemerintah maupun pihak pengelola pasar Surabaya dapat membantu meningkatkan pendapatan dengan memberikan pembinaan yang nantinya juga akan membantu untuk untuk meningkatkan pelayanan terhadap pelanggan pasar Pabean. Hal ini juga dapat menarik lebih banyak wisatawan yang dapat memberikan keuntungan untuk pasar Pabean. Dinas sosial juga dapat terus membantu meningkatkan keterampilan para kuli panggul ini dengan cara memberikan kelas khusus yang disesuaikan dengan waktu kerja perempuan kuli panggul. Melalui hal ini diharapkan pandangan masyarakat terhadap kuli panggul dapat berubah menjadi lebih baik.

\section{Daftar Pustaka}

Aditya, Nicholas R. (2019). "Ini Kisaran Tarif Porter di Stasiun Kereta Api”, (Online). (https://travel.kompas.com/read/2019/11 /22/170000727/ini-kisaran-tarif-porterdi-stasiun-kereta-api-?page=all, diakses 24 Maret 2020).

Estri, Budi (2016). Peran Perempuan Buruh Gendong di Kota Yogyakarta. Jurnal Universitas Muhammadiyah Yogyakarta.

Hapsati, Eunike C. (2013). Perempuan Buruh Gendong di Pasar Tradisional (Studi Kasus di Pasar Bandungan Kecamatan Bandungan Kabupaten Semarang). Skripsi. Universitas Negeri Semarang.

Hartini, T. (2012). Pemberdayaan Ekonomi Perempuan: Keluar dari Kemiskinan. Jurnal Perempuan, 17(3), pp. 65-82.

Hartono, Yudi dan Farah Wahyuni I.S. (2013). Profil Kuli Panggul Perempuan Desa Selotinatah Kecamatan Ngariboyo Kabupaten Magelang. Jurnal Agastya, 03(01), pp. 101-126

Kamus Besar Bahasa Indonesia (2019). "panggul", (Online). (https://kbbi.web. id/kerja, diakses 1 November 2019).

Mosse, Julia Cleves (1996). Gender dan Pembangunan. Yogyakarta: Pustaka Pelajar. 
Tong, Rosemarie Putnam (1998). Feminist Thought: Pengantar Paling Komprehensif kepada Arus Utama Pemikiran Feminis. Yogyakarta: Jalasutra.

Ruspita, Leli (2012). Keterasingan Perempuan dari Pekerjaannya: Kemitraan SuamiIstri dalam Pengelolaan Keuangan Rumah Tangga. Jurnal Perempuan, 17(3), pp. 23-45.

Sadli, Saparinah (2010). Berbeda tetapi Setara: Pemikiran tentang Kajian Perempuan. Jakarta: Kompas Media Nusantara.
Sari, Eva Norma dan Nur Hidayah (2017). Fenomena Kehidupan Buruh Gendong Perempuan di Pasar Giwangan. Skripsi. Universitas Negeri Yogyakarta.

Saptari, Ratna and Brigitte Holzner (2016). Perempuan, Kerja, dan Perubahan Sosial. Jakarta: Kalyanamitra.

Spradley, James P. (2007). Metode Etnografi. Yogyakarta: Tiara Wacana. 